\title{
Enhanced Mustard Productivity and Profitability through Frontline Demonstrations in South-Eastern Rajasthan, India
}

\author{
B.S. Meena ${ }^{1} *$ D.S. Meena ${ }^{1}$, K.C. Meena ${ }^{2}$ and C.B. Meena ${ }^{1}$ \\ ${ }^{1}$ Agricultural Research Station, Ummedganj, Agriculture University, Kota-324001 \\ (Rajasthan), India \\ ${ }^{2}$ KVK, Sawai Madhopur, India \\ *Corresponding author
}

\section{A B S T R A C T}

Frontline demonstrations of mustard were conducted from 2011-12 to 2017-18 in humid South-Eastern Plain Zone- $V$ of Rajasthan to enhance mustard productivity at the farmers'

\section{Keywords}

Mustard, Improved technology,

Farmer's practices,

Frontline

demonstration

Article Info

Accepted:

06 June 2018

Available Online:

10 July 2018 field in adopted villages of Kota and Baran district during rabi 2011-12 and 2017-18.. The selection of farmers was done on the basis of Participator Rural Appraisal (PRA) action plan. The results of seven years front line demonstrations indicated that improved varieties i.e. Bio 902, DMH 1, NRCDR 2, Giriraj and NRCHB 101 of mustard with full package under demonstration had significant impact on seed yield compared to local varieties used by farmers. Further, mean results of the study revealed that additional yield $(352.18 \mathrm{~kg})$, yield increase $(22.21 \%$ ), gross monetary return (₹ 66,293) and additional net monetary return (₹ 8619), additional return (₹ 11778) and IBCR (3.73) from one hectare were obtained over farmer practices by adoption of improved production technology. The improved package of practices i.e. row spacing, fertilizer, irrigation, weed management and plant protection measures including improved varieties NRCHB 101 and Giriraj were followed in demonstrations. Farmers were motivated by results of improved practices applied in the FLDs trials and they would adopt these technologies in the coming years for betterment of farming. It may be concluded that improved production technology of mustard has found more productive, economic viable and also feasible to local conditions as compared to existing farmer practices

\section{Introduction}

Oilseeds play a pivotal role in Indian economy, accounting for $5 \%$ of the gross national product and $10 \%$ of the value of agricultural products. Amongst the oilseed, rapeseed-mustard (Brassica spp.) ranks second in area next only to soybean in India as well as in the world. It is a major rabi oilseed crop of the country cultivated 6.8 million ha area with a production of 8.2 million tones and its average productivity is $1176 \mathrm{~kg} / \mathrm{ha}$ (FAO, 2015). It is the most important rabi season oil seed crop of Rajasthan and grown in 2.21 mha with a production of $2.91 \mathrm{mt}$ and with average productivity of $1316 \mathrm{~kg} / \mathrm{ha}$, thus it has major share in area (46\%) and production (49\%) of rapeseed mustard in India (Anonymous 2009- 
10), which is nutritionally very rich and its oil content varies from $37-49 \%$ but production of this crop need to be enhanced to meet the national short fall. To meet the vegetable oil requirement of the country at optimum level, we have to increase our production from present level of 20 million tones to about 50 million tones by 2020 (Hedge, 2005).

Improved agricultural technologies are the product of modern science which leads to ultimate sustainable production. Mustard (Brassica Juncea) is established as major rabi crop in central part of India. Survey of technology adoption levels of package of practices in Hadoti region (Kota, Bundi, Jhalawar and Baran districts of Rajasthan) indicated that there was either lack of adoption or partial adoption of improved practices resulting in lower productivity levels as compared to their potentially yield levels recorded in the yield maximization trials conducted on the farmer's field on one acre demonstration plots. Least use of improved varieties, higher seed rate, lack of seed treatment with chemical and bio-agents (Azotobactor), inadequate and imbalanced fertilizer use, lack of use of plant protection measures against pest and diseases, poor efficiency in harvest during unfavorable weather conditions, were some of the critical production factors contributed to the poor and stable yield.

To convince the mustard growers on effectiveness of technology and to motivate them for adoption, lying out of demonstration is one of the proven methods. In view this frontline demonstration financed by Department of Agricultural and Co-operation (DAC), through Directorate of rapeseedmustard Research, Bharatpur, ICAR, Govt. of India were conducted by Agricultural Research Station, Ummedganj farm, Kota (Agriculture University, Kota) in the south eastern humid zone $\mathrm{V}$, (Hadoti region) of
Rajasthan to demonstrate the potentials of improved practices (IP) versus farmer's practices (FP) under real farm conditions. Though, a suitable variety with improved technologies for a specific agro-ecological region is important for enhancing productivity of mustard. Therefore, improved production technologies with full package were demonstrated at farmer's field to augment the mustard productivity. This study may be helpful to the mustard grower in doubling farmer income under changing scenario and congenial environment condition.

\section{Materials and Methods}

The study was conducted in humid SouthEastern Plain Zone-V of Rajasthan to enhance mustard productivity under front line demonstrations at the farmers' field in adopted villages of Kota and Baran district during rabi 2011-12 and 2017-18. All the participating farmers were given one day training prior to demonstration on improved production technology of mustard. A total of 180 frontline demonstrations were conducted to evaluate the impact of research emanated production technology on mustard productivity over seven years during rabi 2011- to 2017-18. The improved package of practices i.e. row spacing, fertilizer (recommended dose of fertilizer: $80 \mathrm{~kg} \mathrm{~N}, 40 \mathrm{~kg} \mathrm{P}_{2} \mathrm{O}_{5}$ and $40 \mathrm{~kg} \mathrm{~S} / \mathrm{ha}$, seed inoculated with bio-fertilizers Azotobactor and PSB culture), irrigation, weed management (fluchlorolin @ 1.0 1/ha) and plant protection measures (Quinalphos $1.5 \%$ dust 7-10 days after germination followed by one spray of diamethoate $30 \mathrm{EC}$, $875 \mathrm{ml} / \mathrm{ha}$, seed treatment with emidaclopride $48 \mathrm{FS} 6 \mathrm{~g} / \mathrm{kg}$ seed for sucking pest and apron $35 \mathrm{SD} 6 \mathrm{~g} / \mathrm{kg}$ seed for white rust including improved varieties NRCHB 101 and Giriraj, Bio-902, DMH 1 and NRCDR 2 were followed in demonstrations. The performance of mustard grows with improved technologies were compared with the farmer's practice 
which included $6 \mathrm{~kg}$ own seed/ha without seed treatment, $100 \mathrm{~kg} \mathrm{~N}+50 \mathrm{~kg} \mathrm{P}_{2} \mathrm{O}_{5} / \mathrm{ha}$. Production and economics data of front line demonstrations and farmer practices were collected and analyzed. The selection of cultivators was done on the basis of Participator Rural Appraisal (PRA) action plan and care has been taken to layout the demonstrations on road side facilitate the demonstration of technology. Each frontline demonstration was laid out on 0.5 ha area, adjacent 0.5 ha was considered as control for comparison (farmer's practice). Majority of demonstrations were sown in the first fortnight of October. The soil of the demonstrations fields were clay loam, alkaline in reaction ranges $(\mathrm{pH} 7.75$ to 8.1 ), medium in organic carbon $(0.52$ to $0.55 \%)$, nitrogen (290.0 to $325 \mathrm{~kg} / \mathrm{ha}$ ) and phosphorus (22.4 to 36.5 $\mathrm{kg} / \mathrm{ha}$ ) and high in potassium (312.0 to 340 $\mathrm{kg} / \mathrm{ha}$ ). The nitrogen and phosphorus were given through di-ammonium phosphate and remaining quantity of nitrogen was given through urea applied as basal as well as top dressing at 40-45 DAS. The potassium was applied through murate of potash on soil test basis.

\section{Results and Discussion}

The results of seven years (2011-12 to 201718) front line demonstrations indicated that improved varieties i.e. Giriraj and NRCHB 101 of mustard with full package under demonstration had excellent impact on seed yield compared to local varieties used by farmers (Table 1). Among mustard varieties, variety Giriraj gave the highest $(2550 \mathrm{~kg} / \mathrm{ha})$ yield in the year 2017-18. The next best variety was NRCHB $101(2430 \mathrm{~kg} / \mathrm{ha})$ in the year 2016-17, which is suitable for timely and late sown irrigated condition, followed by Bio-902 (1945 and $1970 \mathrm{~kg} / \mathrm{ha})$ in the year 2011-12 and 2012-13, DMH 1 (1777 $\mathrm{kg} / \mathrm{ha}), \mathrm{NRCDR} 2(1594 \mathrm{~kg} / \mathrm{ha})$ in the year 2013-14, DMH 1 (1750 kg/ha) in the year
2014-15, Giriraj (2213 kg/ha), NRCHB 101 $(2108 \mathrm{~kg} / \mathrm{ha})$ in the year 2015-16,Giriraj (2156 $\mathrm{kg} / \mathrm{ha})$, NRCHB $101(2085 \mathrm{~kg} / \mathrm{ha})$ in the year 2016-17 and Giriraj (2216 kg/ha), NRCHB $101(2004 \mathrm{~kg} / \mathrm{ha})$ in the year 2017-18, thus recorded 17.88, 18.67, 23.37, 21.69, 16.67, 29.46, 28.84 and 23.36 percent, respectively higher seed yield under recommended package of practices over local varieties with farmer's practice. From these results it is evident that the performances of improved varieties were found better than the local checks under local conditions. It could partly be accounted for the interaction between low temperature and nature of mustard varieties. The minimum yield of $1450 \mathrm{~kg} / \mathrm{ha}$ (Improved Practices) and $1310 \mathrm{~kg} / \mathrm{ha}$ (farmer's practice) was recorded in case of variety NRCDR 2 and NRCHB 101 due temperature fluctuation, this showed that high temperature in the season must have caused forced maturity (heat injury) in the season must have suppressed the performance of the variety. Data further revealed that the highest mean seed yield $(1983.45 \mathrm{~kg} / \mathrm{ha})$ recorded under improved practices than farmer practice $(1631.30 \mathrm{~kg} / \mathrm{ha})$ and yield increase over farmer practice was to the tune of $22.21 \%$.

There has been year to year variation in average yield of mustard which varied from 1594 to $2216 \mathrm{~kg} / \mathrm{ha}$ in case of improved practices and 1310 to $1778 \mathrm{~kg} / \mathrm{ha}$ in farmer's practices. This reveals that the adoption of improved production technology of mustard cultivation is capable to enhance the productivity by 22.21 percent over farmers practice. Meena and Meena (2015) reported that the research emanated production technologies are capable of increasing production of mustard by 20-32 percent through frontline demonstration on farmer's field, similarly Dhaka et.al.(2010) observed 26.7 percent increase in yield over local check in case of maize (Table 2). 
Table.1 Yield of mustard in improved and farmers practices through frontline demonstration under real farm situation in Hadoti region of Rajasthan

\begin{tabular}{|c|c|c|c|c|c|c|c|c|}
\hline \multirow[t]{3}{*}{ Year } & \multirow{3}{*}{$\begin{array}{c}\text { Variety used } \\
\text { in IP }\end{array}$} & \multirow{3}{*}{$\begin{array}{l}\text { No of } \\
\text { FLDs }\end{array}$} & \multicolumn{4}{|c|}{ Seed yield (kg/ha) } & \multirow{3}{*}{$\begin{array}{c}\text { YIOFP } \\
(\%)\end{array}$} & \multirow{3}{*}{$\begin{array}{c}\text { AYOFP } \\
\text { (kg/ha) }\end{array}$} \\
\hline & & & \multicolumn{3}{|c|}{ IP } & FP & & \\
\hline & & & Maximum & Minimum & Mean & Mean & & \\
\hline 2011-12 & Bio 902 & 20 & 2350 & 1950 & 1945 & 1650 & 17.88 & 295 \\
\hline 2012-13 & Bio 902 & 20 & 2410 & 2000 & 1970 & 1660 & 18.67 & 310 \\
\hline \multirow[t]{2}{*}{ 2013-14 } & DMH 1 & 10 & 1825 & 1735 & 1777 & 1441 & 23.37 & 336 \\
\hline & NRCDR 2 & 10 & 1620 & 1565 & 1594 & 1310 & 21.69 & 284 \\
\hline 2014-15 & DMH 1 & 20 & 1810 & 1750 & 1750 & 1500 & 16.67 & 250 \\
\hline \multirow[t]{2}{*}{ 2015-16 } & Giriraj & 7 & 2475 & 1675 & 2213 & 1719 & 29.46 & 494 \\
\hline & NRCHB 101 & 13 & 2270 & 1450 & 2108 & 1727 & 28.84 & 381 \\
\hline \multirow[t]{2}{*}{ 2016-17 } & Giriraj & 20 & 2500 & 1500 & 2156 & 1745 & 23.36 & 411 \\
\hline & NRCHB 101 & 20 & 2430 & 1750 & 2085 & 1730 & 20.61 & 355 \\
\hline \multirow[t]{2}{*}{ 2017-18 } & Giriraj & 32 & 2550 & 1840 & 2216 & 1778 & 24.77 & 438 \\
\hline & NRCHB 101 & 8 & 2250 & 1750 & 2004 & 1684 & 19.01 & 320 \\
\hline Mean & & 180 & 2226.36 & 1724.09 & 1983.45 & 1631.27 & 22.21 & 352.18 \\
\hline
\end{tabular}

YIOFP: Yield increase over farmer's practice; AYOFP: Additional yield over farmer's practice; IP: Improved practices; FP: Farmers' Practices;

Table.2 Economics of improved practices under frond line demonstration at farmer's field

(Mean data of 7 years)

\begin{tabular}{|c|c|c|c|c|c|c|c|c|c|c|}
\hline \multirow[t]{2}{*}{ Year } & \multicolumn{2}{|c|}{$\begin{array}{c}\text { Cost of } \\
\text { cultivation } \\
\text { (Rs./ha) }\end{array}$} & \multicolumn{2}{|c|}{$\begin{array}{c}\text { GMR } \\
\text { (Rs./ha) }\end{array}$} & \multirow[t]{2}{*}{$\begin{array}{l}\text { ANMR } \\
\text { (Rs./ha) }\end{array}$} & \multicolumn{2}{|c|}{ B:C Ratio } & \multirow[t]{2}{*}{$\begin{array}{c}\text { Additional } \\
\text { cost } \\
\text { (Rs./ha) }\end{array}$} & \multirow[t]{2}{*}{$\begin{array}{c}\text { Additional } \\
\text { returns } \\
\text { (Rs./ha) }\end{array}$} & \multirow[t]{2}{*}{ IBCR } \\
\hline & IP & FP & IP & FP & & IP & FP & & & \\
\hline 2011-12 & 18882 & 16023 & 58350 & 49500 & 5991 & 2.09 & 2.08 & 2859 & 8850 & 3.10 \\
\hline 2012-13 & 22630 & 20512 & 65010 & 54450 & 8442 & 1.87 & 1.65 & 2118 & 10560 & 4.99 \\
\hline 2013-14 & 24137 & 20908 & 50565 & 41257 & 6079 & 1.09 & 0.93 & 3229 & 9308 & 2.88 \\
\hline 2014-15 & 24200 & 20915 & 56000 & 48000 & 4715 & 2.31 & 2.29 & 3285 & 8000 & 2.44 \\
\hline 2015-16 & 26494 & 22554 & 68306 & 54856 & 9510 & 1.58 & 1.43 & 3940 & 13450 & 3.41 \\
\hline 2016-17 & 26960 & 23418 & 80074 & 64196 & 10336 & 1.90 & 1.74 & 3542 & 13878 & 3.92 \\
\hline 2017-18 & 26567 & 23427 & 85748 & 69346 & 13268 & 2.23 & 1.96 & 3140 & 16408 & 5.23 \\
\hline Mean & 24267 & 21108 & 66,293 & 54,515 & 8619 & 1.87 & 1.73 & 3159 & 11774 & 3.73 \\
\hline
\end{tabular}

CoC: Cost of cultivation; GMR: Gross monetary return; ANMR: Additional Net Monetary Return; IBCR: Incremental benefit cost ratio; B:C: Benefit : Cost

Table.3 Comparative economics of mustard improved practices and farmer practices

(Mean data of 7 years)

\begin{tabular}{|l|c|c|c|c|}
\hline Particulars & $\begin{array}{c}\text { Farmer's } \\
\text { practices }\end{array}$ & $\begin{array}{c}\text { Improved } \\
\text { Practices }\end{array}$ & $\begin{array}{c}\text { Actual increase over } \\
\text { farmer's practices }\end{array}$ & $\begin{array}{c}\text { Increase over farmer's } \\
\text { practice }(\%)\end{array}$ \\
\hline Average yield $(\mathrm{kg} / \mathrm{ha})$ & 1631.27 & 1983.45 & 352.18 & $\mathbf{2 2 . 2 1}$ \\
\hline Gross return $(₹ / \mathrm{ha})$ & 54515 & 66293 & 11778 & $\mathbf{2 1 . 6 1}$ \\
\hline Cost of cultivation $(₹ / \mathrm{ha})$ & 21108 & 24267 & 3159 & $\mathbf{1 4 . 9 7}$ \\
\hline B:C ratio & $\mathbf{1 . 7 3}$ & $\mathbf{1 . 8 7}$ & $\mathbf{0 . 1 4}$ & $\mathbf{8 . 0 9}$ \\
\hline
\end{tabular}


Similar yield enhancement in different crops in frontline demonstration has amply been documented by Mishra et.al. (2009) and Bhawani Shankar and Meena (2015). Variations in yield were observed due to fluctuations and uneven distribution of rainfall in the year. From these results it is evident that the performances of improved varieties were found better than the local checks under real farm situations. Farmers were motivated by results of improved practices applied in the FLDs trials and they would adopt these technologies in the coming years for betterment of farming. The higher yield of mustard could be attributed due to adoption of high yielding improved varieties, line sowing with $30 \mathrm{~cm}$ row spacing, weed management and plant protection measures. These results are also supported by Baldev Ram et al., (2013), Tetarwal et al., (2013) and Meena et al., (2015).

The economics of improved production practice under front line demonstrations were estimated on the basis of prevailing market rates recorded higher gross monetary return ( $₹ 85748$ /ha) and additional return ( ₹ 16408 /ha) with IBCR (5.23) compared to farmer practice in the year 2017-18 and minimum in the year 2016-17 (₹ 64269 /ha, ₹ 14134 /ha and 3.99), respectively. The results suggest that improvement in productivity and economic viability of mustard were obtained by adoption of improved practice under specific agro-ecological situation. Similar result was also reported by Tetarwal et al., (2013). Thus on the basis of average of seven years (Table 3 ) revealed that additional yield $(352.18 \mathrm{~kg})$, yield increase $(22.21 \%)$, gross monetary return (Rs 66,293) and additional net monetary return ( $₹$ 8619), additional return ( $₹$ 11778) and IBCR (3.73) from one hectare were obtained over farmer practices by adoption of improved production technology. The B: $\mathrm{C}$ ratio of improved technologies 1.87 was higher over farmer's practice 1.73. Similarly economics enhancement in different crops in frontline demonstration has also been documented by Dhaka et al., (2015) and Meena et al., (2016).

It may be concluded that improved production technology of mustard has found more productive, economic viable and also feasible to local conditions as compared to existing farmer practices.

\section{References}

Baldev Ram, S.S. Poonia, B.L. Dhaka, M.K. Poonia, B.S. Meena, and Bairwa, R.K.2013. Acceleration of urdbean productivity and profitability under FLDs at humid-eastern plain of Rajasthan. Annals of Agri-Bio research. Vol.18 (3):406-408.

Bhawani Shankar and Meena, K.C. 2015. Nutrient management for enhancing the productivity of Indian mustard (Brassica juncea). Adv. Appl.Res., Vol.7 (1):36-41.

Dhaka B L, B. S. Meena and Suwalka, R. L. 2010. Popularization of Improved Maize Production Technology through Frontline Demonstration in SouthEastern Rajasthan. Journal of Agriculture Sciences 1(1): 39-42.

Dhaka, B.L., M. K., Poonia, B.S. Meena, and Bairwa, R. K.2015. Yield and economic viability of coriander under frontline demonstration in Bundi District of Rajasthan. Journal of Horticultural Sciences Vol.10 (2):226228.

FAO Statistics. 2015. Food and Agriculture Organization of the United Nations Rome. (www.faostat.fao).

Hedge, D.M. 2005. Oilseeds-Striving for self sufficiently. The Hindu Survey of Indian Agriculture. pp. 58-63.

Meena, B.S. and Meena, D.S.2015. Comparative response of Indian 
mustard (Brassica juncea) to sulphur sources on vertisols of Rajasthan. Annals of Agricultural Research New Series 36 (1):1-7.

Meena, B.S., G.S. Meena, and Meena, K.C.2016. Impact study on climate resilient technology demonstrated in NICRA village- Choma kot in Vertisol of Rajasthan. Journal of Progressive Agriculture, Vol.7 (1):42-46.

Meena, D.S., C. Jadon and Meena, B. S. 2015. Impact of Production Technology on Soybean Productivity through Frontline Demonstration.
Annals of Agricultural Research New Series 36 (2): 219-224.

Mishra, D. K., D. K, R. S. Paliwal, Tailor and Deshwal A K. 2009. Impact of Front Line Demonstrations on Yield Encashment of Potato. Indian Journal of Extension Education 9 (3): 26-28.

Tetarwal, J.P., Baldev Ram, D.S. Meena, and Tomar, S.S. 2013. Effect of moisture conservation and sulphur sources on productivity and water use efficiency of Indian mustard (Brassica juncea) under rainfed conditions. Indian Journal of Agronomy 58 (2):231-236.

\section{How to cite this article:}

Meena, B.S., D.S. Meena, K.C. Meena and Meena, C.B. 2018. Enhanced Mustard Productivity and Profitability through Frontline Demonstrations in South-Eastern Rajasthan, India. Int.J.Curr.Microbiol.App.Sci. 7(07): 800-805. doi: https://doi.org/10.20546/ijcmas.2018.707.097 